\title{
OBSTETRICS AND PSYCHOSOCIAL OUTCOME OF TEENAGE PREGNANCY
}

Seetesh Ghose ${ }^{1}$, Lopamudra B John²

\section{HOW TO CITE THIS ARTICLE:}

Seetesh Ghose, Lopamudra B John. "Obstetrics and psychosocial outcome of teenage pregnancy". Journal of Evolution of Medical and Dental Scienc es 2013; Vol. 2, Issue 45, November 11; Page: 8745-8748.

Teenage pregnancy is defined as pregnancies which occur in a female below the age of 20 i.e. when the pregnancy ends. A female can become pregnant as early as two weeks before menarche, although rare, but usually occurs after menarche. In healthy, well-nourished girls, menarche normally takes place around the ages 12 or 13 . A number of personal and social factors are responsible for the onset of biological fertility in a teenage. Teenage pregnancy rates vary between countries because of differences in socio-economic status, traditional culture of early marriage, besides levels of sexual activity, general sex education provided and access to affordable contraceptive options. Worldwide, teenage pregnancy rates range from 143 per 1000 in some subSaharan African countries to 2.9 per 1000 in South Korea.(1)(2) The World Health Organization estimates that the risk of death following pregnancy is twice as great for women between 15 and 19 years than for those between the ages of 20 and 24 . The maternal mortality rate can be up to five times higher for girls aged between 10 and 14 than for women of about twenty years of age. Illegal abortion also holds many risks for teenage girls in areas such as sub-Saharan Africa(3)In our country teenage marriages does take place and pregnancy usually occur after marriage, despite a law against early marriage. Teenage pregnancy is considered to be high-risk due to many reasons because during this period a woman is physiologically and psychologically as well not mature. Their body itself is in growing stage. So to support the growth of the foetus exposes them to additional challenges. Complications of pregnancy result in the deaths of an estimated 70,000 teen girls in developing countries each year. Complications they develop can be grouped into medical, obstetrical, psychological and social. This chapter will highlight obstetrical, psychological and social impact of the teenage pregnancy.

Medical complication: The common medical complications associated with teenage pregnancy are $\mathrm{PIH}$, anaemia and to some extent sexually transmitted disease. The occurrence of PIH in teenage pregnancy is the result of nulliparity and not the age itself. Anaemia in this age group is due to nutritional deficiencies from poor socio-economic status, poor eating habits, attempt to loose weight through dieting, skipping meals, food faddism, snaking and consumption of fast food (4) Young mothers and their babies are also at greater risk of contracting HIV. (5)A recent study revealed there is no difference in the incidence of hypertension, intrauterine growth restriction of foetus, preterm labour and postpartum hemorrhage between teenage pregnancy and pregnancy above 19 years.(6)For mothers in their late teens, age in itself is not a risk factor, and poor outcomes are associated more with socioeconomic factors rather than with biology. Teenage mothers who are given high-quality maternity care have healthier babies than those that do not.

Obstetrical complications: The common antenatal complications are preterm labour leading to premature rupture of membranes due to infection resulting in premature birth, abruption secondary to PIH, anaemia and trauma, prolonged labour, past dates besides post-partum hemorrhage. There is 
no doubt about the incidence of premature birth and low birth weight worldwide, which is higher among adolescent mothers besides receiving inadequate prenatal care. ${ }^{(7)(8)(9)}$

It is a common belief that there is increased operative interference in labour, as an underdeveloped pelvis scan lead to difficulties in child birth. There is strong correlation between increasing patient age and increasing width of pelvis indicating the bony pelvis widen over $20 \mathrm{~mm}$ the ages of 20 and 80.(10)Obstructed labour is normally dealt with by caesarean section; however, in developing regions where medical services might be unavailable, it can lead to obstetric fistula, infant mortality, or maternal death. A recent study on teenage pregnancy showed normal vaginal delivery with episiotomy and a significant lower incidence of caesarean section / perineal tears in teen age mothers compared to other mothers (6)

Psychosocial complications: Many teen parents do not have the intellectual or emotional maturity that is needed to support their offsprings. Often, these pregnancies are hidden for months resulting in a lack of adequate prenatal care and dangerous outcomes for the babies. (11)Mostly teen mothers are drop out of high school.

Teenage motherhood can affect the psychosocial development of the infant as they are less likely to stimulate their infant through affectionate behaviours such as touch,smiling, and verbal communication, or to be sensitive and accepting toward his or her needs.(12) It has been observed that those who had more social support are less likely to show anger toward their children or to rely upon punishment.(13)

The children of teen mothers are prone to various childhood diseases related to anaemia and infections due to prematurity and low birth weight.(14)The children are at higher risk and are usually affected by intellectual, language, and socio-emotional delays.(15) Developmental disabilities and behavioural issues are increased in children born to teen mothers.(12)(16) Poor academic performance in the children of teenage mothers has also been noted, with many of them being more likely than average to fail to graduate from secondary school, be held back a grade level, or score lower on standardized tests. (8)

Daughters born to adolescent parents are more likely to become teen mothers themselves(8)(17)A son born to a young woman in her teens is three times more likely to serve time in prison.(18)

Teen pregnancy can influence younger siblings. One study found that the younger sisters of teen mothers were less likely to emphasize the importance of education and employment and more likely to accept human sexual behaviour, parenting and marriage at younger ages; younger brothers, too, were found to be more tolerant of non-marital and early births, in addition to being more susceptible to high-risk behaviours.(19)If the younger sisters of teenage parents babysit the children, they have an increased risk of getting pregnant themselves.(20)

CONCLUSION: Although teenage pregnancy is considered to be a high risk, early booking , adequate antenatal care and delivery by trained people may develop obstetric and perinatal outcome. However considering its adverse psychosocial impact it need to be discouraged .Many health educators have argued that comprehensive sex education would effectively reduce the number of teenage pregnancies, although opponents argue that such education encourages more and earlier sexual activity. 


\section{REFERENCE:}

1. Treffers PE (2003) Teenage pregnancy, a worldwide problem. Ned Tijdschr Geneeskd 147 (47): 2320-5.

2. UNICEF. (2001). A League Table of Teenage Birth s in Rich.

3. Locoh, Therese. (2000). "Early Marriage and Motherhood In Sub-Saharan Africa." WIN News.'.' Retrieved July 7, 2006

4. Gutierrez Y, King JC (1993). "Nutrition du ring teenage pregnancy". Pediatr Ann 22 (2): 99-108

5. Mayor S (2004). "Pregnancy and childbirth are leading causes of death in teenage girls in developing countries". BMJ 328 (7449): 1152

6. Sagili H, Pramya N, Prabhu K, Mascarenhas M, Reddi Rani P Are teenage pregnancy at high risk? a comparison study in developing country. Arch Gynecol Obstet.2012 Mar,285(3): 573-7

7. Makinson C (1985). "The health consequences of teenage fertility". FamPlann Perspect 17 (3): 132-9.

8. The National Campaign to Prevent Teen Pregnancy (2002)

9. United Nations Statistics Division - Demographic and Social Statistics

10. Berger AA, May R, Renner JB, Viradia N, Dahners LE, Surprising evidence of pelvic growth (widening) after skeletal maturity, J Orthop Res .2011 Nov;29(11):1719-23

11. Day, NL; et al. (2009). "Body Size And Intelligence In 6-Year-Olds: Are Offspring Of Teenage Mothers At Risk?". Maternal\& Child Health Journal

12. American Academy of Paediatrics. Committee on Adolescence and Committee on Early Childhood and Adoption, and Dependent Care (2001). "American Academy of Paediatrics: Care of adolescent parents and their children". Pediatrics 107 (2): 429-34.

13. Crockenberg S (1987). "Predictors and correlates of anger toward and punitive control of toddlers by adolescent mothers". Child Dev 58 (4): 964-75.

14. Statistics on Teen Pregnancy". National Campaign to Prevent Teen Pregnancy

15. Day, NL; et al. (2009). "Body Size And Intelligence In 6-Year-Olds: Are Offspring Of Teenage Mothers At Risk?". Maternal \& Child Health Journal 13 (6)

16. Hofferth SL, Reid L (2002). "Early Childbearing and Children's Achievement and Behavior over Time". Perspectives on Sexual and Reproductive Health 34 (1): 41-49

17. Furstenberg FF, Levine JA, Brooks-Gunn J "The children of teenage mothers: patterns of early childbearing in two generations". Fam Plann Perspect (1990) 22 (2): 54-61)

18. Maynard, Rebecca A. (Ed.). (1996).Kids Having Kids Retrieved May 27, 2006.

19. East, Patricia L. (1996). "Do Adolescent Pregnancy and Childbearing Affect Younger Siblings?". Family Planning Perspectives 28 (4)

20. East PL, Jacobson LJ (2001). "The younger siblings of teenage mothers: a follow-up of their pregnancy risk". Dev Psychol 37 (2): 254-64. 


\section{REVIEW ARTICLE}

\section{AUTHORS:}

1. Seetesh Ghose

2. Lopamudra B John

\section{PARTICULARS OF CONTRIBUTORS:}

1. Professor, Department of Obstetrics \& Gynaecology, Mahatma Gandhi Medical College \& Research Institute, Pilliyarkuppam, Puducherry.

2. Associate Professor, Department of Obstetrics \& Gynaecology, Mahatma Gandhi Medical College \& Research Institute, Pilliyarkuppam, Puducherry.

\section{NAME ADDRESS EMAIL ID OF THE} CORRESPONDING AUTHOR:

Dr. Seetesh Ghose,

Department of Obstetrics \& Gynaecology, Mahatma Gandhi Medical College \& Research Institute, Pilliyarkuppam,

Puducherry - 607402.

Email - seetesh@mgmcri.ac.in

Date of Submission: 16/10/2013. Date of Peer Review: 17/10/2013.

Date of Acceptance: 26/10/2013.

Date of Publishing: 05/11/2013 